\title{
Relaxin as a biochemical marker of placental insufficiency in the horse: a review
}

\author{
P. Ryan', Karen Bennet-Wimbush², Wendy E. Vaala ${ }^{3}$ and Carol A. Bagnel/4 \\ ${ }^{1}$ Mississippi State University, Department of Animal and Dairy Sciences and College of Veterinary Medicine, Mississippi State, USA \\ 2 Ohio State University, Wooster, USA, ${ }^{3}$ Mid-Atlantic Equine Medical Centre, Ringoes, USA, \\ ${ }^{4}$ Rutgers University, Department of Animal Sciences, Cook College. New Brunswick, USA
}

\begin{abstract}
Summary
Placental insufficiency (placentitis, premature placental separation) is regarded as the primary factor contributing to late term abortion and perinatal death in foals. Late term fetal and perinatal death represents a major emotional and financial loss and time investment for horse breeders. All too often when problems associated with late-term pregnancy in the horse are manifested the condition is well advanced and therapeutic intervention may not be effective in salvaging the pregnancy. However, if a compromised pregnancy due to placental insufficiency could be identified early, the pregnancy might be sustained through medical intervention. We present evidence that the placental hormone, relaxin, has the potential to serve not only as a hormonal indicator of placental function and fetal well-being in the mare, but also as a means of monitoring treatment efficacy. A non-invasive diagnostic marker could assist the veterinarian and horse breeder in identifying mares at risk for problematic pregnancies in a timely manner.
\end{abstract}

Keywords: $\quad$ Relaxin, biochemical marker, placental insufficiency equine

\section{Relaxin - eine biochemische Markersubstanz für Plazentaerkrankungen beim Pferd: eine Übersicht}

Plazentaerkrankungen (Plazentitis, vorzeitige Plazentaablösungen) werden als die primären Ursachen für Spätaborte und perinatalen Fohlenverlust angesehen. Gerade die Fohlenverluste in der Spätgravidität und im perinatalen Zeitraum bedeuten für den Züchter neben emotionalen Belastungen große zeitliche und finanzielle Verluste.

Sind plazentare Fehlfunktionen erst einmal klinisch manifest und im Grad fortgeschritten, sind therapeutische Maßnahmen zur Rettung der Leibesfrucht nur noch wenig aussichtsreich. Können jedoch die plazentaren Unterfunktionen rechtzeitig identifiziert werden, so besteht eine Chance, die Trächtigkeit mit medikamentöser Unterstützung zum Termin zu bringen. Im vorliegenden Bericht wird aufgezeigt, dass das Plazentahormon Relaxin nicht nur als Monitorsubstanz für die planzentare Funktion und die Vitalität des Fötus, sondern auch für die Effektivität therapeutischer Maßnahmen eingesetzt werden kann. Als ein nichtinvasiver diagnostischer Marker ist die gezielte Messung von Relaxin für Tierarzt und Pferdezüchter hilfreich, Stuten mit Risikograviditäten rechtzeitig zu erkennen.

Schlüsselwörter: Relaxin, biochemischer Marker, plazentare Unterfunktion Stute

\section{Introduction}

The equine industry would benefit from a hormonal indicator that reflects placental and fetal well-being in the horse. Pregnancy loss during the third trimester and death of foals weakened by abnormal periparturient events constitute a large percentage of fetal and neonatal mortality (Vaala and Sertich, 1994). Due to the expense of breeding contracts and the long gestation of the mare, late-term fetal death represents a major financial loss and time investment for the breeder. Early identification of placental insufficiency would make it possible to sustain the pregnancy through medical intervention. Furthermore, aggressive prepartum therapy affords foals a better-chance of survival. For example, when placental function is compromised in mares suffering from fescue toxicosis, timely drug therapy to rescues the placenta and improves pregnancy outcome (Redmond et al., 1994; Cross et al., 1995; Bennet-Wimbush et al., 1998). Likewise, if diagnosed early, placentitis can be treated with systemic antibiotics, progestins (progesterone, $17 \alpha$ - hydroxyprogesterone, $5 \alpha$-pregnanes), non-steroidal anti-inflammatory drugs or steroids (cortisol, to hasten fetal organ maturation).

Current research is focused on the evaluation of equine placental function in a non-invasive manner. Serum-based hormone assays have been used in the past to determine pregnancy and fetal viability in the horse (Terqui and Palmer, 1979; Stabenfeldt et al., 1991). However, they have not been useful in predicting problematic pregnancies in late gestation. To our knowledge, there is no simple hormonal diagnostic aid available to veterinarians to predict problematic pregnancies and deliveries and reduce the incidence of late-term abortions and perinatal deaths in horses. Relaxin, a placental hormone that can be measured in systemic blood in high concentrations (Stewart et al., 1982; Stewart, 1986), has the potential to be a valuable clinical tool for both diagnosing placental insufficiency and monitoring the efficacy of treatment strategies. Here we review some recent evidence supporting a diagnostic role for relaxin in identifying problematic pregnancies.

\section{Placental insufficiency and late-term abortion}

Vaala and Sertich (1994) have developed three categories to which mares with at risk pregnancies can be assigned: 1) mares with histories of problematic pregnancies, deliveries, and/or birth of compromised foals, 2) mares with reproductive abnormalities, premature udder development, systemic 
illness, and 3) mares with no apparent risk factors that experience an abnormal periparturient event. Examples of recurrent periparturient problems include premature placental separation, dystocia, placentitis, premature delivery and prolonged gestation. Conditions developing during gestation that increase the risk of an abnormal pregnancy outcome regardless of the mare's past reproductive history include severe maternal illness and debilitation, acute abdominal crisis, uterine discharge, premature lactation and twinning (Tab. 1). However, one of the main factors contributing to placental insufficiency and late term abortion is placentitis. Giles and colleagues (1993) reviewed pathology case records of 3,500 aborted fetuses, still-born foals and foals that died within 24 hours of birth to determine cause of death. Their findings indicated that over $60 \%$ of cases were associated with some form of placental insufficiency (placentitis, premature placental separation, placental thickening) that contributed to pregnancy loss and perinatal death. Subsequent studies have identified placentitis as the single most common factor contributing to late term abortion and perinatal death of foals (Hong et al., 1993). Untreated placentitis can result in premature delivery, neonatal sepsis and peripartum hypoxia (i.e. dummy foal syndrome). Such foals are subjected to high mortality and often survive only with expensive intensive care. Another factor that contributes to placental insufficiency is fescue toxicosis resulting from grazing of endophyte-infected tall fescue. Tall fescue is an important forage grass for horses in the United States (Hoveland, 1993; Putnam et al., 1991). However, it frequently is infected with an endophyte, Acremonium coenophialum (Lyons et al., 1986) which produces ergot alkaloids that cause adverse effects in pregnant mares (Porter and Thompson, 1992). Consequences of fescue toxicosis include placental thickening, premature placental separation, complicated deliveries, prolonged gestation, dystocia, agalactia (poor milk production) and high foal mortality (Putnam et al., 1991; Cross et al., 1995). Pregnant mares that suffer from fescue toxicosis have reduced serum prolactin and progesterone (McCann et al.,

Tab. 1: Factors that contribute to placental insufficiency and late-term abortion in the mare

Faktoren, die zur plazentaren Unterfunktion und zu Fohlenverlusten in der Spätgravidität führen.

\begin{tabular}{|ll|}
\hline Maternal & Placental \\
\hline Hydrops allantois, amnii & Premature placental separation \\
\hline $\begin{array}{l}\text { Oligohydrallantois, } \\
\text { Oligohydramniois }\end{array}$ & Small placenta (twins) \\
\hline Abdominal surgery & Placentitis \\
\hline Severe endometrial fibrosis & Vasculitis \\
\hline Purulent vaginal discharge & Congenital anomalies \\
\hline Severe malnutrition & Umbilical cord complications \\
\hline Severe maternal illness & Developmental anomalies \\
\hline Pelvic injuries & Thrombosis infarction \\
\hline Fescue toxicosis & \\
\hline
\end{tabular}

1992). Foal mortality is attributed to dysmaturity and hypoxia due to poor blood flow to the placenta.

\section{Relaxin and pregnancy}

The polypeptide hormone relaxin is a member of the family of insulin-like molecules and is found in highest tissue concentrations during pregnancy in many species, including the rat, rabbit, pig and horse (see Sherwood 1994). It has several important functions during pregnancy and at time of parturition. For example, relaxin promotes uterine growth to accommodate growing fetuses (Hall et al., 1990; Hall et al., 1992) and inhibits myometrial contractions during pregnancy (Watts et al., 1988). In addition, it loosens the pelvic ligaments and dilates the uterine cervix of the rat (Steinetz et al., 1959), sow (Kertiles and Anderson, 1979; O'Day et al., 1989), cow (Grahm and Darcy, 1952) and human (MacLennan et al., 1980) to facilitate parturition.

Several studies have demonstrated the importance of relaxin during pregnancy and at delivery in different species (Sherwood, 1994). Relaxin is essential for the live delivery of pups in the rat (Downing and Sherwood, 1985; Lao-Guico-Lamm and Sherwood, 1988) and piglets in the sow (Nara et al., 1982). Furthermore, relaxin treatment improves calving in beef and dairy heifers by advancing the dilatation of the cervix and increasing pelvic area, thereby decreasing the incidence of dystocia (Musah et al., 1986; Musah et al., 1988; Bagna et al., 1991). Also, there is evidence that the aborting dog exhibits depressed serum relaxin prior to pregnancy loss (Steinetz et al., 1996). In addition, women with symptoms of impending miscarriage in early pregnancy had lower levels of relaxin compared to women with normal pregnancies Witt, et al., 1990; Stewart et al., 1993). This led to the suggestion that relaxin might be a useful epidemiological tool in predicting pregnancy outcome in women (Stewart et al., 1993).

\section{Relaxin in the mare}

The placenta is the primary source of relaxin in the horse during pregnancy (Stewart et al., 1982; Klonisch et al., 1995) although the ovary may be an important source during the reproductive cycle (Ryan et al., 1997a). The purification of equine relaxin from placental tissue has led to its biochemical characterization (Stewart and Papkoff, 1986) and development of a homologous equine relaxin radioimmunoassay (Stewart, 1986). While plasma relaxin is low in non-pregnant mares, during pregnancy relaxin increases from day 80 , peaks at day 175 and is elevated until foaling (Stewart et al., 1992). However, shortly after expulsion of the placenta, relaxin titres decline rapidly and return to pregestational levels (Stewart, 1986). Little is known concerning the role of relaxin in equids during pregnancy and parturition. There is some variation among breeds with respect to relaxin profiles during pregnancy (Stewart et al., 1992); however, the functional significance of these differences in terms of actions of relaxin is unknown. There is some evidence that relaxin secretory pattern is com- 
promised during at risk pregnancies and complicated deliveries. Stewart and co-workers (1992) reported that plasma relaxin levels were low in three standardbred mares with abnormal termination of pregnancy and suggested that relaxin might be a useful indicator of placental function.

\section{Evidence that relaxin is a useful marker of placental function}

In recent years we have collected data that supports this view, and our working hypothesis that relaxin could be used as a true biochemical marker of placental function, fetal well being and predictor of pregnancy outcome in the mare. To this end, a retrospective analysis of plasma relaxin was performed on mares (light breeds) that were presented to the Perinatology Unit at the New Bolton Centre, University of Pennsylvania, with problematic pregnancies (Ryan et al., 1997b). Factors contributing to problematic pregnancies included placentitis, premature placental separation, hydrops, oligohydrallantois, twinning and mares with pituitary tumors. Blood was collected during the third trimester of pregnancy and plasma relaxin was determined using a homologous equine relaxin radioimmunoassay (Stewart, 1986). In a population of mares with normal pregnancies and deliveries, systemic relaxin ranged from $45.0-85.0 \mathrm{ng} / \mathrm{ml}$, with a mean weekly value of $63.0 \mathrm{ng} / \mathrm{ml}$ during the last 7 weeks of gestation. Plasma relaxin declined markedly in mares with problematic pregnancies. Relaxin concentrations in a mare with placentitis declined during the last 45 days of gestation from $53.0 \mathrm{ng} / \mathrm{ml}$ (day 298 of gestation) to a low of $33.0 \mathrm{ng} / \mathrm{ml}$ (day 312), with an average concentration of $46.0 \mathrm{ng} / \mathrm{ml}$. Plasma relaxin was severely depressed in two mares with pituitary tumors, with mean levels of 14.1 and $8.6 \mathrm{ng} / \mathrm{ml}$. Two mares with pregnancy-related fluid problems, one with hydrops and the second with oligohydrallantois (Fig. 1a) had variable relaxin titres, with mean values of 33.2 and $42.3 \mathrm{ng} / \mathrm{ml}$, respectively. An ultrasound scan of the pregnancy on day 302 of gestation indicated loss of fetal fluid and severe folding of the fetal membranes (Fig. 1b). The foal from the latter mare was euthanized at birth due to severe hypoxia and sepsis (Fig. 1c). In the case of a mare with a twin pregnancy, systemic relaxin declined from a high of $68.9 \mathrm{ng} / \mathrm{ml}$ on day 244 to a low of $6.1 \mathrm{ng} / \mathrm{ml}$ on day 301 of gestation. The mare delivered both foals (day 332), one of which was dead (mummified) at Abb. 1: (a) Zirkulierendes Relaxin einer Stute mit Oligohydrallantois und einer Traberstutenpopulation mit normaler Trächtigkeit und Abfohlung. Oligohydrallantois ist eine reduzierte Allantoisflüssigkeit, die zu plazentarer Insuffizienz und Embryodefekten führen kann. Die mittlere Trächtigkeitsdauer bei den normalen Stuten betrug 343 Tage; die Abfohlung der Stute mit Oligohydrallantois erfolgte an Tag 325. Die Pfeile markieren den Abfohltermin. (b) Ultrasonographiebefund der Stute mit Oligohydrallantois am 302. Tag der Trächtigkeit. Beachte den Verlust fetaler Flüssigkeit und die Fältelung der fötalen Membranen (Pfeil). (c) Kleines unreifes Fohlen kurz nach der Geburt am Trächtigkeitstag 325 mit Hypoxie, schweren neuromotorischen Störungen und Sepsis; (Euthanasie nach 24 Stunden wegen ungünstiger Überlebensprognose). birth and the second was euthanized at 4 weeks of age. In all pregnancies in which systemic relaxin was low, foals were
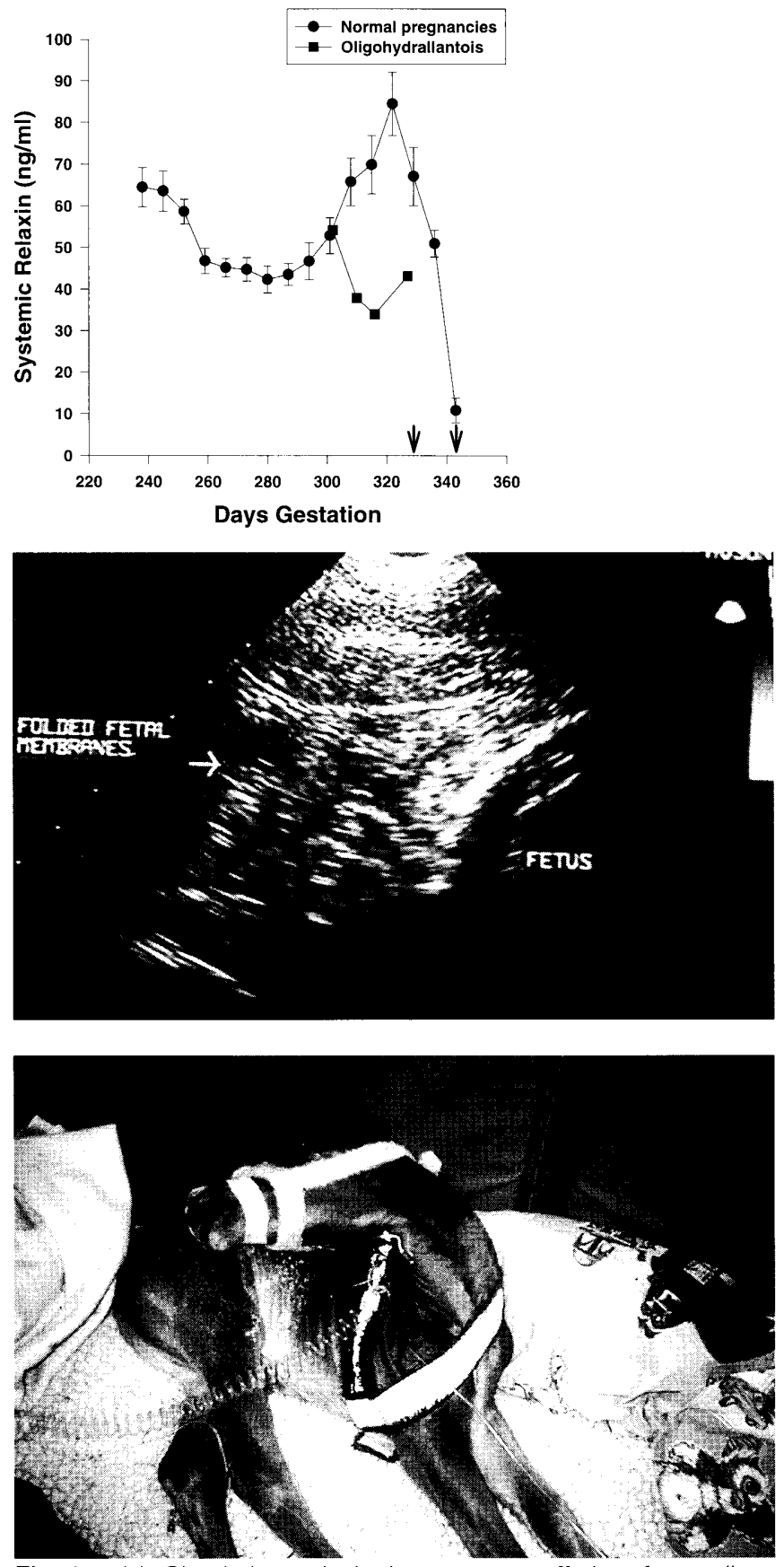

Fig. 1: (a) Circulating relaxin in a mare suffering from oligohydrallantois and a population of Standardbred mares with normal pregnancies and deliveries. Oligohydrallantois is a deficiency of allantoic fluid that can result in placental insufficiency and embryonic defects. Average length of gestation in normal mares was 343 days; delivery in the mare with oligohydrallantois was at day 325 . The arrows indicate day of parturition. (b) Ultrasound scan of the mare with oligohydrallantois at day 302 of gestation. Note the loss of fetal fluids and folding of fetal membranes (arrow). (c) Photograph showing a small, dysmature foal shortly after delivery on day 325 of gestation suffering from hypoxia and severe neurological signs and sepsis. Foal was euthanized 24 hours after birth due to poor prognosis for survival. 
born hypoxic and immature but survived with aggressive medical intervention.

In another study, we determined the effects of fescue toxicosis and fluphenazine (a long acting $\mathrm{D}_{2}$-dopamine antagonist) on relaxin concentrations in pregnant pony mares (Ryan et al., 1998). This study is an extension of a previous study that examined serum prolactin and the efficacy of fluphenazine as a treatment for fesuce toxicosis in pregnant pony mares (Bennet-Wimbush et al., 1998). Mares grazed on endophyte-infected fescue pasture (80\% infected) were treated with either saline or a one-time injection of $25 \mathrm{mg}$ of fluphenazine deconate (i.m.) on day 320 of gestation. Blood was collected daily from day 300 of gestation and assayed for relaxin. Mean relaxinconcentrations in both groups of mares during the week prior to treatment were variable but not different (saline, $53.3+8.5$ $\mathrm{ng} / \mathrm{ml}$; fluphenazine, $62.0+9.9 \mathrm{ng} / \mathrm{ml}$ ). In the two weeks prior to delivery, there was a marked difference in relaxin between treatments; this effect was most dramatic during the last week of gestation (saline, $45.7+6.7 \mathrm{ng} / \mathrm{ml}$; fluphenazine, $64.6+7.2 \mathrm{ng} / \mathrm{ml}$ ). Figure 2 shows representative relaxin profiles for three mares, one receiving fluphenazine and the other two, saline. Three of six saline-treated mares exhibited signs of fescue toxicosis (placental thickening, stillbirth, and agalactia), while one fluphenazine-treated mare showed obvious clinical symptoms. This same mare also shown had depressed plasma prolactin concentrations (see Bennet-Wimbush, 1998). Whether there is an association between depressed relaxin and prolactin in problematic pregnancies has yet to be

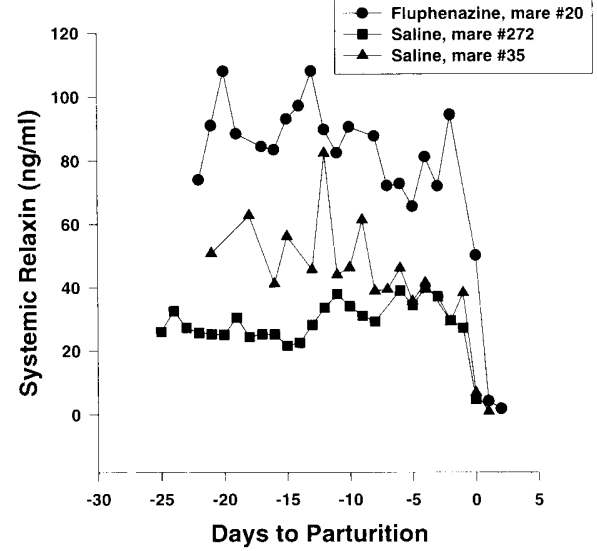

Fig. 2: Systemic relaxin profiles of three individual pony mares are shown. Pony mares were grazed on endophyte-infected tall fescue pasture or hay throughout pregnancy and were either given a one-time injection of saline or fluphenazine deconate $(25 \mathrm{mg}$ i.m.) on day 320 of gestation. The profiles shown are those for the last 20-25 days of gestation. Mare \#20 was treated with fluphenazine while mares \#272 and \#35 were not. In the absence of fluphenazine treatment, plasma relaxin was markedly depressed.

Relaxinprofile von drei individuellen Ponystuten. Die Stuten wurden während der Trächtigkeit auf Weiden mit Wiesenschwingelbewuchs gehalten oder mit wiesenschwingelhaltigem Heu gefüttert und erhielten eine Einmalinjektion entweder von saliner Lösung oder Fluphenazin (25 mg i.m.) an Tag 320 der Trächtigkeit. Gezeigt werden die Relaxinprofile der letzten 20-25 präpartalen Tage. Stute \#20 erhielt Fluphenazin, Stuten \#272 und \#35 blieben unbehandelt. Ohne Applikation von Fluphenazin erfolgte eine deutliche Reduzierung des Relaxinspiegels. determined. Plasma relaxin concentrations were depressed in pregnant mares exhibiting signs of fescue toxicosis. Hence, the lower relaxin concentrations in affected mares might be attributed to a compromised placenta. The clinical observations suggest that a one-time injection of fluphenazine improved pregnancy outcome by reducing the adverse effects of fescue toxicosis concomitant with sustaining plasma relaxin.

\section{Significance}

Some of the standard reproductive management practices for performance horses have added to the incidence of parturient complications in mares. For example, some horse owners breed on the foal heat or mate fillies earlier than three years of age. The incidence of dystocia is estimated to be about $4 \%$ in thoroughbreds, $10 \%$ in draft breeds and higher than $10 \%$ in miniature horses (Vandeplassche, 1993). The need for a simple, reliable marker of placental function in the horse is evident. It is our contention that an enzymelinked immunoabsorbent assay (ELISA) for relaxin could be valuable in assessing at risk pregnancies, and allow time for intervention to sustain the pregnancy and maintain a healthy foal. We are currently developing an equine relaxin ELISA for this purpose. However, relaxin is not a panacea for all pregnancy problems in the mare, nor will screening for relaxin salvage early pregnancy losses, most of which are thought to be associated with genetic anomalies. Furthermore, whether relaxin could be used therapeutically during pregnancy to ensure normal delivery in the mare has yet to be established, since sufficient quantities of relaxin for this type of study are not available. However, until we can test the feasibility of relaxin as a therapeutic agent, the importance of relaxin to the equine industry is in providing the horse owner/veterinarian with a reliable, non-invasive marker of placental function. Systemic levels of relaxin provide a „window" through which the clinician can view the function of the equine placenta. This information, supported by ultrasound data of the placenta, is critical in deciding whether therapeutic intervention is necessary to sustain the pregnancy and ensure delivery of healthy foals.

\section{Literature}

Bagna, B., Schwabe, C. and Anderson, L. (1991): Effect of relaxin on facilitation of parturition in dairy heifers. Journal of Reproduction and Fertility 91, 605-615.

Bennet-Wimbush, K. and Loch, W. (1998): A preliminary study on the efficacy of fluphenazine as a treatment for fescue toxicosis in gravid pony mares. Journal of EquineVeterinary Science 18, 169-173.

Cross, D.L., Redmond, L.M. and Strickland, J.R. (1995): Equine fescue toxicosis: signs and solutions. Journal of Animal Sciences 73, 899-908.

Downing, S.J. and Sherwood, O.D. (1985): The physiological role of rela$x$ in in the pregnant rat. I. The influence of relaxin on parturition. Endocrinology 116, 1200-1205.

Giles, R.C., Donahue, J.M., Hong, C.B., Petrites-Murphy, M.B., Poonacha, K.B., Roberts, A.W., Smith, B.J., Tramontin, R.R. and Swerczek, T.W. (1993): Causes of abortion, stillbirth and perinatal death in horses: 3,527 cases (1986-1991). Journal of the American Veterinary Medical Association (JAVMA) 203, 1170-1175. 
Grahm, E.F. and Darcy, A.E. (1952): The effect of relaxin and mechanical dilation on the bovine cervix. Journal of Dairy Science 36, 772-777.

Hall, J.A., Cantley, T.C., Day, B.N. and Anthony, R.V. (1990): Uterotropic actions of relaxin in prepbubertal gilts. Biology of Reproduction 42, 769-774.

Hall, J.A., Cantley, T.C., Galvin, J.M., Day, B.N. and Anthony, R.V. (1992): Influence of ovarian steroids on relaxin-induced uterine growth in ovariectomized gilts. Endocrinology 130, 3159-3166.

Hong, C.B., Donhahue, J.M., Giles, R.C., Petrites-Murphy, M.B., Poonacha, K.B., Roberts, A.W., Tramontin, R.R., Smith, B., Tuttle, P.A. and Swerczek, T.W. (1993): Equine abortion and stillbirth in central Kentucky during 1988-1989 foaling seasons. Journal of Veterinary Diagnostics and Investigation 5, 560-566

Hoveland, C.S. (1993): Importance and economic significance of the Acermonium endophytes to performance of animals and grass plants. Agricultural Ecosystem and Environment 44, 33-

Kertiles, L.P and Anderson, L.L. (1979): Effect of relaxin on cervical dilation, parturition and lactation in the pig. Biology of Reproduction. 21, 57-68.

Klonisch, T., Ryan, P.L., Yamashiro, S. and Porter, D.G. (1995): Partia complementary deoxyribonucleic acid cloning of equine relaxin messenger ribonucleic acid, and its localization within the equine placenta. Biology of Reproduction 52, 1307-1315.

Lao-Guico-Lamm, M.L. and Sherwood, O.D. (1988): Monoclonal antibodies specific for rat relaxin. II. Passive Immunization throughout the second half of pregnancy disrupts birth in intact rats. Endocrinology 123 , 2472-2478.

Lyons, P.C., RD and Bacon, C.W. (1986): Occurrence of peptide and clavine ergot alkaloids in tall fescue grass. Science 232, 487-489.

MacLennan, A.H., Green, R.C., Bryant-Greenwood, G., Greenwood, F.C. and Semark, R.F. (1980): Ripening of the human cervix and induction of labor with purified porcine relaxin. Lancet 1, 220-223.

McCann, S.J., Caudle, A.B., Thompson, F.N., Steudemann, J.A., Heushner, G.L. and Thompson Jr., D.L. (1992): Influence of endophyte-infected tall fescue on serum prolactin and progesterone in gravid mares. Journal of Animal Science 70, 217-223.

Musah, A.l., Schwabe, C., Willham, R.L. and Anderson, L.L. (1986): Relaxin induction of parturition in beef heifers. Endocrinology 118 1476-1482.

Musah, A.l., Schwabe, C., Willham, R.L. and Anderson, L.L. (1988): Dystocia, pelvic and cervical dilatation in beef heifers after induction of parturition with relaxin combined with cloprostenol or dexamethasone. Animal Reproduction Science 16, 237-365

Nara, B.S., Welk, F.A., Rutherford, J.E. and Sherwood, O.D. (1982): Effect of relaxin on parturition and frequency of live births in pigs. Journal of Reproduction and Fertility 66, 359-365

O'Day, M.B., Winn, R.J., Easter, R.A., Dzuik, P.J. and Sherwood, O.D. (1989): Hormonal control of the cervix in pregnant gilts III. Relaxin's influence on cervical biochemical properties in ovariectomized hormonetreated pregnant gilts. Endocrinology 129, 1967-1976.

Porter, J.K. and Thompson, F.N. (1992): Effects of fescue toxicosis on reproduction in livestock. Journal of Animal Science 70, 1594-1603.

Putnam, M.R., Bransby, D.I., Schumacher, J., Boosinger, T.R., Bush, L., Shelby, R.A., Vaughan, J.T., Ball, D. and Brendemuehl, J.P. (1991): Effects of the fungal endophyte Acremonium coenophialum in fescue on pregnant mares and foal viability. American Journal of Veterinary Research 52, 2071-2074.

Redmond, L.M., Cross, D.L., Strickland, J.R. and Kennedy, S.W. (1994): Efficacy of domperidone and sulpiride as treatments for fescue toxicosis in horses. American Journal of Veterinary Research 55, 722-729.

Ryan, P.L., Bennet-Wimbush, K., Loch, W., Vaala, W. and Bagnell, C.A. (1998): Effects of fescue toxicosis and fluphenazine on relaxin concentrations in pregnant pony mares. Proceedings 44th Annual Convention of American Association of Equine Practitioners 44, 60-61.

Ryan, P.L., Klonisch, T., Yamashiro, S., Renaud, R., Wasnidge., C and Porter, D.G. (1997a): Expression and localization of relaxin in the ovary of the mare. Journal of Reproduction and Fertility 110, 329-338.

Ryan, P.L, Vaala, Wendy and Bagnell, Carol (1997b): Equine relaxin: a diagnostic tool for placental insufficiency and parturient complications in the mare. Proceedings 15th Equine Nutrition and Physiology Symposium, Fort Worth, Texas, May 28-31, 1997.
Sherwood, O.D. (1994): Relaxin. In: The Physiology of Reproduction, Second Edition. E. Knobil and JD Neill (eds), Raven Press L.td., New York, NY, pp 861-1009.

Stabenfeldt, G.H., Daels, P.F., Munro, C.J., Kindahl, H., Hughes, J.P. and Lasley, B. (1991): An oestrogen conjugate enzyme immunoassay for monitoring pregnancy in the mare. Journal of Reproduction and Fertility Supplement $44,37-44$.

Stewart, D.R. (1986): Development of a homologous equine relaxin radioimmunoassay. Endocrinology 119, 1100-1104.

Stewart, D.R, Addiego, L.A., Pascoe, D.R., Haluska, G.J. and Pashen, R. (1992): Breed difference in circulating equine relaxin. Biology of Reproduction 46, 648-652.

Stewart, D.R., Overstreet, J.W., Celniker, A.C., Hess, D.L., Cragun, J.R., Boyers, S.P. and Lasley, B.L. (1993): The relationship between hCG and relaxin secretion in normal pregnancies vs peri-implantation spontaneous abortions. Clinical Endocrinology 38, 379-385.

Stewart, D.R. and Papkoff, H. (1986): Purification and characterization of equine relaxin. Endocrinology 119, 1100-1104.

Stewart, D.R., Stabenfeldt, G.H., Hughes, J.P. and Meagher, D.M. (1982): Determination of the source of equine relaxin. Biology of Reproduction 27, 17-24

Steinetz, B.G., Beach, V.L. and Kroc, R.L. (1959): The physiology of relaxin in laboratory animals. In: Recent Progress in the Endocrinology of Reproduction. C. Lloyd (ed). Academic Press, New York, NY, pp 389-427.

Steinetz, B.G, Bullesbach, E.E., Goldsmith, L.T., Schwabe, C. and Lust, G. (1996): Use of a synthetic canine relaxin to develop a rapid homologous radioimmunoassay. Biology of Reproduction 54, 1252-1260.

Terqui, M. and Palmer, E. (1979): Oestrogen pattern during early pregnancy in the mare. Journal of Reproduction and Fertility 27, 441-446.

Vaala, W.E. and Sertich, P.L. (1994): Management strategies for mares at risk for periparturient complications. In: The Veterinary Clinics of North America, Equine Practice, Perinatology. WE Vaala (guest ed), WB Saunders, Philadelphia, PA, pp 237-265.

Vandeplassache, M. (1993): Dystocia. In: Equine Reproduction. AO McKinnon, JL Voss (eds). Lea and Febiger, Philadelphia, PA, pp 537-542.

Watts, A.D., Flint, A.P.F., Foxcroft, G.R. and Porter, D.G. (1988): Plasma steroid, relaxin and dihydro-keto-prostaglandin F-2 alpha changes in the mini-pig in relation to myometrial electrical and mechanical activity in the pre-partum period. Journal of Reproduction and Fertility 83, 553-564.

Witt, B.R., Wolf, G.C., Wainwright, C.J., Johnston, P.D. and Thorneycroft, I.H. (1990): Relaxin, CA-125, progesterone, estradiol, Schwangerschaft protein, and human chorionic gonadotropin as predictors of outcome in threatened and non-threatened pregnancy. Fertility and Sterility 53, 1029-10.

\section{Acknowledgements}

The authors would like to thank Dr. Patricia Sertich, New Bolton Centre, University of Pennsylvania and Dr. David Meirs, Walnridge Farms, New Jersey, for collecting blood samples from mares, and Drs. Judy Lenhart, Kathleen Ohleth, Ms. Colleen Boa, Ms. Jackie Agans and Ms. Anita Grochulski for technical assistance. We extend a special thanks to Dr. Larry Katz (Rutgers University) for his help with relaxin iodination, Dr. Dennis Stewart, University of California at Davis, for the generous gift of relaxin and antiserum, and Dr. Bill Tucker, Mississippi State University, for helpful comments on the manuscript. Financial support provided by New Jersey Agricultural Experiment Station Special Initiative Fund (Equine) 1996-99.

\section{Dr. Peter Ryan}

Mississippi State University

4025 Wise Centre

P.O. Box 9815

Mississippi State, MS 39762, USA

e-mail:pryan@ads.msstate.edu

FAX: 601-325-8873 